\title{
A Contemporary Perspective on Therapeutic Measures and Approaches to Pain Management in Lung Cancer
}

\author{
Akciğer Kanserindeki AğrıIı, Tedavi Edici Önlem ve Yaklașımlara Güncel bir Bakıș Açısı
}

\author{
Hande Türker', Çetin Kürșad Akpınar², Meftun Ünsal ${ }^{3}$ \\ ${ }^{1}$ Department of Neurology, Medical Faculty, Ondokuz Mayıs University, Samsun, Turkey; ${ }^{2}$ Neurology Service, Vezirköprü State \\ Hospital, Samsun, Turkey; ${ }^{3}$ Department of Chest, Medical Faculty, Ondokuz Mayıs University, Samsun, Turkey
}

\begin{abstract}
Lung cancer is the commonest malignancy worldwide, and 80$90 \%$ of patients die within one year of diagnosis. Since it is usually very difficult and sometimes impossible to cure lung cancer radically, the precautions and therapy modalities chosen as palliative measures for the improvement of quality of life of the cancer patient become more important than the curative treatments. Lung cancer also commonly induces moderate to severe pain, but little is known of the extent of this complex problem. The aim of this review is to highlight current treatment modalities for the pain associated with lung cancer and to suggest a broader perspective in its study and management.
\end{abstract}

Key words: cancer pain; lung cancer; neuropathic pain

\section{ÖZET}

Akciğer kanseri dünyadaki en yaygın kanser türüdür ve hastaların \%80-90'ı tanıda bir yıl sonra ölmektedir. Akciğer kanserinin kesin tanısı genellikle zordur ve bazende imkansızdır. Kanser hastalarının yașam kalitesinin iyileștirilmesi için palyatif tedbirler olarak seçilen önlemler ve tedavi yöntemleri kesin tedavi kadar önemlidir. Ayrıca akciğer kanseri orta ve șiddetli ağrıya neden olur, ama bu karmașık sorun ufak ölçüde bilinmektedir. Bu derlemenin amacı, akciğer kanseri ile ilișkili ağrı için mevcut tedavi yöntemlerini vurgulamak ve tedavinin çalıșma ve yönetimi daha geniș bir bakıș açısı ile önermektir.

Anahtar kelimeler: kanser ağrısl; akciğer kanseri; nöropatik ağrı

\section{Introduction}

According to a study by Hauser et al, prognostic factors in patients with advanced cancer can be conceptualised as attributes of the host, tumour and treatment, and interactions among the three reflected in symptoms, quality of life performance status and laboratory

Uzm. Dr. Cetin Kürşad Akpınar, OMÜ Tip Fakültesi Nöroloji Polikliniği 55200 Samsun-Türkiye,Tel.05422262605Email.dr_ckakpinar@hotmail.com Geliş Tarihi: 05.05.2015 • Kabul Tarihi: 26.06.2015 tests ${ }^{1}$. Pain is a major problem that has a great impact in the quality of life of cancer patients.

In spite of the continuing study of the physiology and biochemistry of pain, it remains true that cancer pain is only partially understood. Pain is often experienced as several different types, with combined somatic and neuropathic types the most frequent ${ }^{2}$.

Neuropathic pain results from damage to or dysfunction of the peripheral or central nervous system, rather than stimulation of pain receptors. Diagnosis is suggested by pain out of proportion to tissue injury, dysesthesia (e.g. burning, tingling), and signs of nerve injury detected during neurologic examination ${ }^{3}$.

Nociceptive pain may be somatic or visceral. Somatic pain receptors are located in skin, subcutaneous tissues, fascia, other connective tissues, periosteum, endosteum, and joint capsules. Stimulation of these receptors usually produces sharp or dull localized pain, but burning is not uncommon if the skin or subcutaneous tissues are involved. Visceral pain receptors are located in most viscera and the surrounding connective tissue. Visceral pain due to obstruction of a hollow organ is poorly localized, deep, and cramping and may be referred to remote cutaneous sites. Visceral pain due to injury of organ capsules or other deep connective tissues may be more localized and sharp ${ }^{3}$.

The prevalence of cancer pain varies from $5 \%^{4}$ to $100 \% 5$ among studies. The type and stage of cancer accounts for some of this variability. Lung cancer, head and neck cancer and genito-urinary cancer cause particularly high levels of pain ${ }^{7,8,9}$, and in general, those with advanced cancer are more likely to experience pain than those with early disease $\mathrm{e}^{10,11}$. 
A survey by IASP (International Association for the Study of Pain $)^{12}$ reported that pain interpreted by the clinician to be nociceptive and due to somatic injury occurred in $71.6 \%$ of patients. Pain labeled nociceptive was noted in $34.7 \%$ of subjects and pain attributable to neuropathic mechanisms occurred in $39.7 \%$ of subjects. In a broad classification, the major pain syndromes comprised bone or joint lesions (41.7\%), visceral lesions (28.1\%), soft tissue infiltration (28.3\%), and peripheral nerve injuries (27.8\%). Twenty-two types of pain syndrome were most prevalent. This wide IASP survey of 1,095 patients confirmed that cancer pain characteristics, syndromes and pathophysiologies are very heterogeneous.

In a study designed by a group of Japanese cancer researchers, nociceptive pain was the most common, occurring in $85 \%$ of patients, and neuropathic pain in $33 \%{ }^{13}$. For these reasons, pain control in cancer is centered on opioid therapy, and therefore adequate use of opioids becomes important ${ }^{14,15}$.

In a study by Mercadante et al, sixty consecutive lung cancer patients referred to a palliative care service were followed until death to obtain detailed information about the prevalence, characteristics and location of pain. Satisfactory relief of somatic incident pain was not achieved, while patients with neuropathic pain were not disadvantaged compared to those exhibiting somatic or visceral pain ${ }^{16}$.

Lung cancer causes a very high frequency of distressing symptoms and survival in the majority of patients is measured in months, not years ${ }^{17}$. Pain is one of the most common symptoms causing distress in the final months and weeks of life.

\section{Somatic Pain in Lung Cancer}

Specifically, lung cancer can cause pain locally by invading the parietal pleura, ribs, thoracic spinal cord or brachial plexus or elsewhere in the body by metastasis. In addition, the short and long term consequences of radiotherapy and chemotherapy treatments can be painful $^{7,18}$.

The skeleton is one of the most common sites of metastasis in patients with lung cancer. The incidence of bone metastases in lung cancer patients is approximately $30-40 \%$, and the median survival time of patients with such metastases is 6-7 months ${ }^{7}$. Metastatic bone disease leads to various complications or skeletally related events, including pain.
The prevention and treatment of bone metastases is mainly dependent on effective treatment against lung cancer itself. Radiation therapy, surgery and bisphosphonates are the principle direct treatments for bone metastases ${ }^{19}$. However, pain is not always adequately controlled by high doses of specific medication, radiation therapy or chemotherapy. When these therapies do not provide adequate pain relief, percutaneous vertebroplasty, cementoplasty, radiofrequency ablation and internal radiotherapy appear to be efficient complementary pain control methods ${ }^{20}$. In considering bisphosphonates, they inhibit osteoclast-mediated bone resorption by binding to bone minerals, interfering with osteoclast activation. These agents also promote repair by stimulating osteoblast differentiation and bone formation. As a result, these agents are playing an increasing role in the treatment of painful bone metastases ${ }^{21}$.

Pancoast's syndrome is produced by apical lung tumor, with a local extension to the inferior brachial plexus, paravertebral sympathetic chain, vertebral bodies and first, second and third ribs. Its major cause is non-small cell lung cancer, and it may produce shoulder pain and Horner's syndrome. The best diagnostic method is transthoracic needle aspiration, because of its peripheral location. Neoadjuvant chemo-radiotherapy followed by complete surgical excision is the preferred approach to these tumors ${ }^{22}$.

Pain is especially a problem when there is chest wall involvement or bony metastases. Careful use of appropriate analgesics based on the 'WHO analgesic ladder' is the mainstay of treatment, but it is important to recognize opioid-resistant pain. Occasionally nerve root block or even cordotomy are required for intractable symptoms. Palliative radiotherapy is also an important component of pain management in some patients ${ }^{23}$.

In the late 1980's, a pain-free state for most patients with advanced cancer seemed unattainable ${ }^{23}$. Since then many studies have been undertaken to assess the prevalence and nature of cancer pain and they have helped reduce the level of pain experienced by most lung cancer patients by offering a broader suite of complementary treatments ${ }^{2,23}$.

The most common pain sites reported by persons with lung cancer are the chest and lumbar spine. Nociceptive and somatic pains are the major subtypes of pain, but neuropathic pain accounts for $30 \%{ }^{24}$. Silvestri et al reported that the three main causes of malignancy-related pain in lung cancer are skeletal metastases (34\%), Pancoast tumor (31\%) and chest wall disease $(21 \%)^{25}$. 
Skeletal metastases usually present with localized pain. Palliative radiotherapy is the mainstay of treatment for painful skeletal metastases, complemented with optimal oral, transdermal or parenteral analgesia ${ }^{24}$. According to a review on teletherapy and radiopharmaceutical therapy of painful bone metastasis, many questions remain as to the optimal use of radiopharmaceuticals, including whether combinations of radiopharmaceuticals with each other, with bisphosphonates or with chemotherapy can further improve therapeutic outcomes ${ }^{26}$.

The pain in Pancoast tumors may be severe and unrelenting, worsened by movement of the affected arm, and often develops months before diagnosis ${ }^{27}$. Treatment includes vigorous efforts to achieve local control. Radiotherapy alone at a dose of 6,000 cGy is the usual treatment; however, complete surgical excision, when possible, achieves the most appreciable pain control ${ }^{28}$. Pre- and postoperative radiotherapy is also considered appropriate. Pharmacological management of superior sulcus pain syndrome is very challenging and includes the use of opioids, neuropathic agents, and interventional pain therapy ${ }^{24}$. Chest wall pain may be due to direct chest wall extension by the tumor which can cause radicular pain. Chest wall pain can also be treatment-related, such as post-thoracotomy pain, or pain subsequent to pleural drainage and pleurodesis ${ }^{24}$.

\section{Neuropathic Pain in Lung Cancer}

The identification of a neuropathic pain syndrome in a cancer patient requires a focused clinical evaluation based on knowledge of common neuropathic pain syndromes. If a tumor is directly involved in the etiology of the pain, oncologic treatment is an initial consideration and may include surgery, radiation, or chemotherapy. There is no single accepted algorithm for the analgesic treatment of neuropathic pain and a systematic approach utilizing therapeutic trials of specific agents at gradually increasing doses is warranted ${ }^{29}$.

Neuropathic pain is a common syndrome in cancer patients. Its pathophysiology is not fully understood, often leading to poor management and needless suffering. Knowledge of the potential mechanisms of neuropathic pain, skill in both interpreting the case history and physical-assessment techniques, and awareness of the more common neuropathic pain syndromes and their etiologies, as well as familiarity with the role of new pharmacologic interventions, should allow healthcare professionals to provide better relief of neuropathic pain. At present, a variety of agents are used to treat neuropathic pain situations. Rehabilitation of persons with neuropathic pain should both be part of overall management and specifically address functional impairment and safety factors to prevent accidents resulting from sensory $\operatorname{loss}^{30}$.

Increases in our understanding of the function of the neurologic system over the last few years have led to new insights into the mechanisms underlying pain symptoms, especially chronic and neuropathic pain ${ }^{31}$. At present, therapeutic options for the traetment of neuropathic pain are largely limited to drugs approved for other conditions, including anticonvulsants, antidepressants, antiarrhythmics, and opioids. Therefore, treatment based on the underlying disease state (eg, postherpetic neuralgia, diabetic neuropathy) may be less than optimal, in that two patients with the same neuropathic pain syndrome may have different symptomatology and thus respond differently to the same treatment.

Cancer pain syndromes may arise from the interruption of bone, viscera, and neural structures by malignant spread of the disease ${ }^{32}$. However, not only malignant spread, but paraneoplastic effects of cancer may cause neuropathies leading to neuropathic pain ${ }^{33}$.

The shoulder-hand syndrome is a paraneoplastic syndrome that can cause neuropathic pain in lung cancer and is described by many authors as a sequela of myocardial infarction, hemiplegia and cancer of the lungs. The syndrome evolves in a form that resembles the post-traumatic algodystrophies. Pain, stiffness and tenderness of the shoulder, coupled with limited movement indistinguishable from capsulitis, are usually the first symptoms and these sometimes progress to swelling, pain, stiffness and discoloration of the hand ${ }^{33}$.

According to a study by Potter and Higginson, pain experienced by lung cancer patients is usually of mixed pathophysiology and a relatively high proportion is attributable to neuropathic mechanisms ${ }^{7}$.

Neuropathic pain may be a consequence of malignant invasion of neurological structures (including Pancoast tumours) or neurological damage resulting from antineoplastic treatment. Neuropatic pain may also contribute disproportionately to the duration and intensity of pain because it is difficult to identify and is relatively resistant to conventional analgesic treatment ${ }^{34,35}$. Despite this, early diagnosis and treatment are critical to the prevention of irreversible neurological damage and chronic neuropathic pain in cancer patients ${ }^{36}$. 
Chemotherapy-induced peripheral neuropathy (CIPN) is a major dose-limiting side effect of many commonly used chemotherapeutic agents, including platinum drugs, taxanes, epothilones and vinca alkaloids, and also newer agents such as bortezomib and lenolidamide ${ }^{37}$. Taxanes produce asymmetric, axonal, predominantly sensory distal neuropathy, with less prominent motor involvement ${ }^{38}$. Regrettably, there are currently no effective symptomatic treatments for paclitaxel-associated pain, myalgias and arthralgias. However, tricyclic antidepressants and anticonvulsants have been used with some success to treat the symptoms of neurotoxicity ${ }^{38}$.

The current authors earlier reported a lung cancer patient suffering from severe pain and concluded from his therapy follow-ups that gabapentin seemed to be reliable even at high doses, and may become the first choice treatment in the taxane-induced arthralgias and myalgias which usually accompany neuropathic pain ${ }^{39}$.

The disabling condition of metastatic plexopathy often accompanies advanced systemic cancer and may involve any of the peripheral nerve plexuses. Brachial plexopathy most commonly occurs in carcinoma of the breast and lung, and lumbosacral plexopathy is most commonly associated with colorectal and gynecologic tumors, sarcomas, and lymphomas. Regardless of the location, neoplastic plexopathy is often characterized by severe, unrelenting pain ${ }^{40}$.

Facial pain can, on rare occasions, be the presenting symptom of lung cancer ${ }^{16}$. The pain is frequently described as severe and aching, and may be continuous or intermittent and is typically neuropathic. In the literature, there are only a few case reports on this subject ${ }^{41-43}$.

To our knowledge, treatment of neuropathic pain in cancer patients does not have any specifically stated guidelines. However, the EFNS (European Federation of Neurological Societies) Task Force published guidelines in 2006 and advised the use of gabapentin, pregabalin and tricyclic antidepressants (TCA) as the first line of drugs in painful neuropathy, whereas lamotrigine, opioids, serotonin-noradrenalin reuptake inhibitors (SNRIs) and tramadol were recommended as second line drugs ${ }^{44}$. Seven of the patients had lung cancer and all patients had high scores of LANSS (The Leeds Assessment of Neuropathic Symptoms and Signs) which indicated that their pain was neuropathic rather than nociseptive ${ }^{45}$.

Our clinical observations generally correspond with a recent review on neuropathic cancer pain, according to which, drugs used in non-cancer neuropathy appear to be effective in cancer-induced pain states ${ }^{46}$.

Very recently, alpha-lipoic acid has been shown to be neuroprotective against chemotherapy-induced neurotoxicity. Mitochondrial toxicity is an early, common event both in paclitaxel and cisplatin induced neurotoxicity ${ }^{47}$. Paclitaxel and cisplatin are used very commonly in lung cancer treatment. Alpha-lipoic acid protects sensory neurons through its anti-oxidant and mitochondrial regulatory functions, possibly by inducing the expression of frataxin. These findings suggest that alpha-lipoic acid might reduce the risk of the development of peripheral nerve toxicity in patients undergoing chemotherapy and encourage further confirmatory clinical trials ${ }^{47}$.

Because pain is a common cause of distress in lung cancer, pain control is a high priority in the supportive care of this population ${ }^{23}$. However, it is usually underdiagnosed and its management needs further consideration.

The current authors believe that a detailed history of pain should be obtained from both patients and care givers. Frequent visits to patients or at least seeing them regularly in the outpatient clinic may help achieve better understanding of the pain these patients suffer from.

We currently have many different treatment modalities for lung cancer induced pain when compared to the past. Patients with advanced disease often experience multiple symptoms, including fatigue, pain, dyspnea, coughing, hemoptysis and anorexia ${ }^{48}$. Unfortunately, survival rates have not improved in the past 30 years, despite considerable research in diagnostics and therapeutics. The sharing of interdisciplinary knowledge must become a higher priority to help improve the therapy and outcomes of these patients.

\section{References}

1. Hauser CA, Stockler MR, Tattersall MHN. Prognostic factors in patients with recently diagnosed incurable cancer: a systematic review. Support Care Cancer 2006;15:999-1011.

2. Grond S, Zech D, Diefenbach C, et al. Assessment of cancer pain: a prospective evaluation in 2, 266 cancer patients referred to a pain service. Pain 1996;64:107-14.

3. The Merck Manuals Online Medical Library. Section: Neurologic Disorders. Subject: Pain 2003.

4. Greenwald HP, Bonica JJ, Bergner M. The prevalance of pain in four cancers. Cancer 1987;60:2563-9.

5. Coyle N. The last four weeks of life. Am J Nursing 1990;90:72-5. 
6. Ventafridda V, Ripamonti C, De Conno F, et al. Symptom prevalance and control during cancer patients last days of life. J Palliat Care 1990;6(3):7-11.

7. Potter J, Higginson IJ. Pain experienced by lung cancer patients: a review of prevalance, causes and pathophysiology. Lung cancer 2004; $43: 247-57$.

8. Brescia FJ, Adler D, Gray G, et al. Hospitalised advanced cancer patients: a profile. J Pain Symptom Manage 1990;5(4):221-7.

9. Vainio A, Auvinen A. Members of the Symptom Prevalence Group. Prevalence of symptoms among patients with advanced cancer: an international collaborative study. J Pain Symptom Manage 1996;12:3-10.

10. Portenoy RK. Cancer pain: epidemiology and syndromes. Neurol Clin 1999;63(11):2298-307.

11. Portenoy RK. Cancer pain: pathophysiology and syndromes. The Lancet 1992;330:1026-31.

12. Caraceni A, Portenoy RK. An international survey of cancer pain Characteristics and syndromes. IASP Task Force on cancer pain. International Association for the Study of Pain. Pain 1999;82:263-74.

13. Murakawa K, Moriyama K, Yanamoto F, et al. Cancer pain management modalities and positioning of oxycodone. Eur $\mathrm{J}$ Pain 2007; 1:48-52.

14. Grond S, Radbruch L, Meuser T, et al. Assessment and treatment of neuropathic cancer pain following WHO guidelines. Pain 1999;79:15-20.

15. Levy MH. Pain control in patients with cancer. Oncology 1999;13(2):9-14.

16. Mercadante S, Armata M, Salvaggio L. Pain characteristics of advanced lung cancer patients referred to a palliative care service. Pain 1994;59(1):141-5.

17. Peake FM. Lung cancer and its management. Medicine 2007;36:162-7.

18. Slavik E, Ivanovic $S$, Grujicia D. Cancer pain (classification and pain syndromes). Acta Chir Iugosl 2004;51(4):9-14.

19. Tsuya A, Fukuoka M. Bone metastases in lung cancer. Clin Calcium 2008;18:455-9.

20. Kastler B, Boulahdour H, Barral FG, Lerais JM, et al. Pain management in bone metastasis of pulmonary origin: new interventional and metabolic techniques. Rev Mal Respir 2005;22:94-100. (Article in French)(Abstract)

21. Pandit-Taskar N, Batraki M, Divgi CR. Radiopharmaceutical therapy for palliation of bone pain from osseous metastases. J Nucl Med 2004;45(8):1358-65.

22. Khosravi Shahi P. Pancoast's syndrome (superior pulmonary sulcus tumor): Review of the literature. An Med Interna 2005;22:194-6.

23. Portenoy RK. Cancer Pain, Epidemiology and Syndromes. Cancer 1989;63:2298-307.

24. Joyce M, Schwartz S, Huhmann M. Supportive Care In Lung Cancer. Sem Oncol Nurs 2008;24:57-67.

25. Silvestri GA, Sherman C, Williams T, et al. Caring for the dying patient with lung cancer. Chest 2002;122:1028-36.

26. Silberstein EB. Teletherapy and Radiopharmaceutical Therapy of Painful Bone Metastases. Semin Nucl Med 2005;35:152-8.

27. Ginsberg R, Payne D, Shamji F. Superior sulcus tumors. In: Aisner J, Arriagada R, Green M, Martini N, Perry M, eds. Comprehensive textbook of thoracic oncology. Baltimore, MD. Williams \&Wilkins; 1996, pp 375-87.
28. Guerrero M, Williams S. Pancoast tumor. E-Medicine. Available at: http://www. emedicine. com/radio/topic515. htm 2004(accessed March 23, 2007).

29. Martin LA, Hagen NA. Neuropathic pain in cancer patients: mechanisms, syndromes, and clinical controversies. J Pain Symptom Manage 1997;14:99-117.

30. Paice JA. Mechanisms and management of neuropathic pain in cancer. J Support Oncol 2003;1(2):107-20.

31. Harden RN. Chronic neuropathic pain. Mechanisms, diagnosis, and treatment. Neurologist 2005;11:111-22.

32. Shaiova L. Difficult pain syndromes: bone pain, visceral pain, and neuropathic pain. Cancer J 2006;12(5):330-40.

33. Turker H, Unsal M, Onar M. Peripheral and central nervous system involvement in lung cancer. TJC 2007;37(1):5-10.

34. Portenoy RK. Neuropathic pain. In: Portenoy RK, Kanner RM, editors. Pain management: theory and practice. Philadelphia: FA Davis; 1996. p.83-125.

35. McQuay $H$. Opioids in pain management. The Lancet 1999;253:2229-32.

36. Elliot K, Foley KM. Neurologic pain syndromes in patients with cancer. Crit Care Clin 1990;6(2):393-420.

37. Wolf S, Barton D, Kottschade L, et al. Chemotherapy-induced peripheral neuropathy: prevention and treatment strategies. Eur J Cancer 2008;44(11):1507-15.

38. Argyriou AA, Koltzenburg M, Polychronopoulos P, et al. Peripheral nerve damage associated with administration of taxanes in patients with cancer. Crit Rev Oncol Hematol 2008;66(3):218-28.

39. Turker H, Unsal M, Onar M. Gabapentin in taxane induced artralgia. Pain Clinic 2006;18(3):271-6.

40. Jaeckle KA. Neurological manifestations of neoplastic and radiationinduced plexopathies. Semin Neurol 2004;24(4):385-93.

41. Sarlani E, Schwartz AH, Greenspan JD, et al. Facial pain as first manifestation of lung cancer: a case of lung cancer-related cluster headache and a review of the literature. J Orofac Pain 2003;17(3):262-7.

42. Schoenen J, Broux R, Moonen G. Unilateral facial pain as the first symptom of lung cancer: are there diagnostic clues? Cephalgia 1992;12(3):178-9.

43. Bindoff LA, Heseltine D. Unilateral facial pain in patients with lung cancer: a referred pain via the vagus? Lancet 1988;1(8589):812-5.

44. Attal N, Cruccu G, Haanpaa M, et al. EFNS Task Force. EFNS guidelines on pharmacological treatment of neuropathic pain. Eur J Neurol 2006;13(11):1153-69.

45. Bennett M. The LANSS Pain Scale: the Leeds assessment of neuropathic symptoms and signs. Pain 2001;92(1-2):147-57.

46. Urch CE, Dickenson AH. Neuropathic pain in cancer. Eur J Cancer 2008;44(8):1091-6.

47. Melli G, Taiana M, Camozzi F, et al. Alpha-lipoic acid prevents mitochondrial damage and neurotoxicity in experimental chemotherapy neuropathy. Exp Neurol 2008;214(2):276-84.

48. Pearman T. Psychosocial factors in lung cancer: quality of life, economic impact, and survivorship implications. J Psychosoc Oncol 2008;26(1):69-80. 